\title{
In memoriam: Professor Heinz Zemanek (1920-2014)
}

\author{
Cliff B. Jones \\ Department of Computing Science, University of Newcastle Upon Tyne, Newcastle Upon Tyne NE1 7RU, UK
}

Heinz Zemanek played a key leadership role in many areas beyond that of Formal Methods. He always insisted that he was an engineer ('if it works, it is true') and while still at the Technical University of Vienna, he led the team that created Mailüfterl which was the first transistor-based computer built in mainland Europe (the name translates as 'Spring Breeze' which was a self-deprecating play on the name of the American 'Whirlwind' machine). To the broad world of information processing, Heinz was probably best known for his unstinting commitment to IFIP of which he was President from 1971 to 1974. Within IBM his singular talents were marked by him being made an IBM Fellow in 1976.

Focussing in on Formal Methods, Heinz brought into existence the famous series of IFIP Working Conferences with that in 1964 on Formal Language Description Languages held in Baden-bei-Wien. This was, like so much that he touched, a masterpiece of timing; the Proceedings (edited by Tom Steel) came out in 1966 under the same title and are still an invaluable reference point for those trying to understand how research on formal semantics began.

The success of the engineering group from the TU led to its move into IBM and ultimately being promoted to a fully independent laboratory with Heinz as its first director. He was prescient enough to realise (what the company was far slower to accept) that the future was software and the work for which the IBM Lab Vienna will be best known to readers of this journal is that of formal language descriptions. Initially, descriptions of PL/I were written in an operational style which was dubbed by Peter Wegner as the Vienna Definition Language. Later, the Lab embraced the ideas of denotational semantics and the Vienna Development Method has had a significant direct impact in industrial use and has influenced many subsequent methods.

Heinz was above all a leader who created the environment for others to flourish. In 2005, Gerhard Chroust organised a 'bunch of flowers' for Heinz's 85th birthday celebration: each of the 17 wooden blooms bore the photo of one of Heinz's colleagues who was officially a professor (and a significant number of former colleagues who did not have that title could have easily transitioned into such a post had they not been doing things they preferred elsewhere). Personally, my two stays in the Vienna Lab (1968-1970; 1973-1976) were among the most enjoyable periods of my career and I owe all of my colleagues a huge debt of gratitude. My particular debt to Heinz was that he made it all possible.

This short note is mainly to draw attention to the full Gedenkschrift being published under the editorship of Karl Anton Froeschl, Gerhard Chroust and Johann Stockinger: 'In memoriam Heinz Zemanek', OCG Journal 39:5 (special issue), Wien: OCG, 2015 (ISSN 1728-743X). The OCG Journal will contain a full list of his numerous honours. 